\title{
Circadian rhythm of cell population structure of Rauwolfia serpentina Benth under different culture conditions in vitro
}

\author{
I.Yu. Parnikoza, N.Yu. Miriuta' ${ }^{1}$ V.I. Adonin' ${ }^{1}$ V.A. Kunakh ${ }^{1}$ \\ National Taras Shevchenko University of Kyiv, \\ 64, Volodymyrska Str., Kyiv 01033 Ukraine \\ ${ }^{1}$ Institute of Molecular Biology and Genetics, NAS of Ukraine \\ 150, Zabolotny Str., Kyiv 03680 Ukraine \\ kunakh@imbg.org.ua; Parnikoza@gmail.com
}

\begin{abstract}
A thermodynamic approach was used to study the correlation between the incidence of cells with various DNA content in nucleus and the proliferation rate (mitoses and amitoses). These biological fluxes and forces were analyzed at the circadian hierarchic level upon changes in the culture conditions for the Rauwolfia serpentina K-27 strain, a producent of ajmaline, the anti-arrhythmic alkaloid.
\end{abstract}

Keywords: plant tissue culture, Rauwolfia serpentina, circadian cell population rhythm in vitro

Introduction. Plant tissue cultures are characterized by high level of cytogenetic variability $[1,2]$. Previously we have reported several studies of quantitative cell subpopulation dynamics with different relative content of DNA (rcDNA) in nucleus depending on nucleolus area as well as dynamics of specific rate of productivity accumulation indexes during the passage for different cultivation variants of a high productive K-27 strain of Rauwolfia serpentina Benth - a medicinal plant used as a source of indoline alkaloids. In those studies we have used the mathematical model specifically developed for conjugated processes in physical, chemical and biological systems, which was called the thermodynamic approach. This model contains a sys-

(C) I.Yu. PARNIKOZA, N.Yu. MIRIUTA, V.I. ADONIN, V.A. KUNAKH, 2008 tem of equations virtually characterizing a network of cross interactions or conjugated processes.

The mathematical model (thermodynamic of irreversible process) published in [3, 4], which was initially developed for describing of higher organism's tissue growth and differentiation, can be undoubtedly applied for studying of higher plant's tissue culture. The only problem is to select appropriately the fluxes, forces and phenomenological coefficients and to ascribe them the biological significance. During cultures passing we have conducted some experiments that allowed us to chose and to ascribe the biological significance for the fluxes, forces and phenomenological coefficients as well as to determine the dimension coefficients that have been described in detail in [5]. The contribution of dynamics of the quantitative content of 
corresponding subpopulations (as biological forces) to dynamics of biological fluxes i.e. specific rates of productivity accumulation index has been studied and analyzed [3-6]. At the lowest hierarchy level, i.e. a circadian, the alteration dynamics of the quantitative content of different cell subpopulations with rcDNA in nucleus have been considered to be fluxes and circadian dynamics of quantitative content of proliferating cells - to be forces, since the physiological phenomena in tissue cultures, in particular the proliferation activity, had circadian rhythm $[2,7]$.

Indeed, the quantity gradient of "cells with certain DNA content in nucleus" versus "biological development time" under transition to the lowest hierarchy level has been considered to be the rate of accumulation of cells with the same characteristic, i.e. biological flux. If the principles of linearity for the dependence of biological fluxes on presumed biological forces, according to Curie and Onsager, are fulfilled, one may conclude about successful choice of selected fluxes and forces [8]. On the other hand, descending one step in relaxation time hierarchy to the level, where the slowest molecular oscillators act, authors of [9-11] have shown on yeast culture that the expression group consisting of five genes, which control three states of cell differentiation in culture, form a network of post-transcriptional regulation, where the specificity of one gene in the group is determined by a higher number of connections [10]. However, during studying the multiple cells interactions at this hierarchy level [9-11], the cell quantity in population, simultaneously synthesizing the same transcripts, has been estimated by indirect methods. When estimating the quantity of cell subpopulations, corresponding to different physiological states, we used the statistical approach, which was similar to the method described in [10]. But, in contrast, we tried to present our results (that also represent a network of interactions at the level of cell population) by the system of differential equations.

In the current work we make an effort to describe the contribution of biological forces, i.e. the alteration dynamics of proliferating (by mitoses or amitoses) cell portion into biological fluxes, i.e. the alteration dynamics of portion of cell subpopulations with different relative DNA content (rcDNA) in nucleus, under different cultivation conditions of $R$. serpentina K-27 strain.
Materials and Methods. Object of investigation. Genetically stable (during last 15 years) K-27 strain of tissue culture of $R$. serpentina (150 passages) was studied under standard cultivation conditions in $10 \mathrm{~S}$ medium, containing $10 \%$ sucrose (variant K-27(10 S), that was described in $[2,12])$. Cultivation of $\mathrm{K}-27$ strain was also studied by the manner of a submerged culture in liquid nutrient medium Rzh (K-27(Rzh) variant). Rzh medium differs from $10 \mathrm{~S}$ medium by four fold lower concentration of sucrose $(2.5 \%)$ and by the reduced content of macro- and micro-salts as well [13, 14]. Besides, this medium was recommended for industrial cultivation of $R$. serpentina tissues [15]. It's important to point out that K-27(Rzh) variant of cells is very sensitive to some modifications of cultivation method, for example, transition from agar to shaking in liquid medium and significant variations of sucrose and salts concentrations in nutrient medium. All these changes of cultivation conditions may result in physiological stress for K-27(Rzh). All cultural variants were grown in darkness in this study due to the reason that original tissue culture was grown in darkness for 44 years since the moment of its creation.

For both analyzed variants of cell strains, samples were taken out every two hours of growth to study passage dynamics. Additionally, to conduct circadian investigation the samples were taken out at the same time points every two hours but only when the production of indoline alkaloids had maximal levels, namely $12-15^{\text {th }}$ days of growth for K-27(10 S) and 9-1 $1^{\text {th }}$ days - for K-27(Rzh) variant. More details of culturing conditions and productivity were published elsewhere [12, 14 , and 15]. Pieces of callus ( $1 \mathrm{~g}$ in average) were withdrawn every two hours from two flasks, starting at 10 a.m. of the first investigation day, and ending at 8 a.m. of the last investigation day. Taken material was immediately placed into the mixture of glacial acetic acid and $96 \%$ ethanol (1:3) and after 24 hours transferred to $70 \%$ ethanol, where it was kept until staining.

DNA content in nuclei of interphase cells was determined. Felgen's method was used for cells staining, as described in $[16,17]$. Images of 100 stained cell nuclei prepared from four different tissue parts were taken using optic system, consisting of a green light filter of NU-2E microscope (Carl Zeiss, Austria), red light filter of CCD Sac-410 PA digital camera, and Asus V 
3000 video driver. The signal of stained interphase nucleus was quantified using Scion Image software. Relative DNA content (designated as C) was calculated as a ratio of peak area of stained nucleus to the peak area of stained anaphase nucleus. Taking into account that anaphase nucleus has 4C DNA, the abovementioned ratio was multiplied by factor 4 to obtain the actual number of $\mathrm{C}$ in the measured sample.

Determination of proliferation indexes. Squashed cells samples stained with aceto-orcein were prepared as described in [17]. Mitotic and amitotic indexes (MI and AMI, respectively) were calculated after analysis of 5 thousand cells prepared from different parts of callus tissue (four different preparations). The data obtained were used to build circadian dynamics of respective proliferation index. Dynamics' of mitoses and amitoses quotas $\left(\mathrm{MI}^{*} 0.01\right.$ or $\left.\mathrm{AMI} * 0.01\right)$ were used as biological forces.

Statistic analysis. 100 cells from every sample was taken and according to the rcDNA in nucleus distributed into separate morphometrical classes (Table 1), thus, the dynamics of cell distributions according to rcDNA was obtained. An axial section along the temporal axis was made for every class. The portion of cells at each moment was multiplied by the portion of cells of this class in the general data selection (Table 1), thus, the dynamics' of cell portions with different rcDNA in nucleus for several morphometrical classes, presented in Table 1, were obtained (Fig.1). These curves as well as the dynamics' of mitoses and amitoses quotas (calculated for 5000 cells using standard method) were smoothed by two points moving average method. After that, the dynamics' of cell portions with different rcDNA in nucleus were compared with the dynamics' of proliferation indexes using the method of paired linear regression according to [18]. Correlation coefficients and corresponding value of criterion statistics were calculated according to the formula, indicated in the legend for Table 2. If the correlation was insignificant, corresponding coefficients were considered to be equal to zero.

Under the principle of thermodynamic approach, we will consider the alteration dynamics of the cell portion, according to the value of rcDNA in the nucleus, for cell subpopulations, selected at the each passage, as biological fluxes on circadian hierarchy level [6].
Table 1

Share of cell classes with different relative DNA content in nucleolus in general cell population of different cultivation variants of the $K-27 R$. serpemtima strain.

\begin{tabular}{|c|c|c|}
\hline \multirow{2}{*}{$\begin{array}{l}\text { Relative DNA content, } \\
\text { C }\end{array}$} & \multicolumn{2}{|c|}{ Share of the class } \\
\hline & K-27 (10 S) & K-27 (Rzh) \\
\hline \multicolumn{3}{|c|}{ First subpopulation } \\
\hline$<1$ & 0,0003 & 0,0006 \\
\hline $1-2,99$ & 0,2761 & 0,1717 \\
\hline \multicolumn{3}{|c|}{ Second subpopulation } \\
\hline $3-4,99$ & 0,5867 & 0,5303 \\
\hline $5-6,99$ & 0,1189 & 0,2292 \\
\hline $7-8,99$ & - & 0,0569 \\
\hline \multicolumn{3}{|c|}{ Third subpopulation (not involved) } \\
\hline $7-8,99$ & 0,0133 & - \\
\hline $9-10,99$ & 0,0028 & 0,0083 \\
\hline$>11$ & 0,0019 & 0,0031 \\
\hline
\end{tabular}

Linear dependences between dynamics of cell portions of corresponding subpopulations and dynamics of mitoses and amitoses quotas, which may be considered as biological forces, were determined by paired linear regression method according to [18]. Further calculation procedure was described in details in [5]. To estimate the adequacy of computed curves to experimental ones we used the normal distribution evaluation method with zero mathematical expectation of the deviations squares between compared curves [18].

Results and Discussion. During tissue culture of $R$. serpentina K-27(10 S) and K-27(Rzh) strains passaging two main subpopulation of cells were used. Each of them contained different rcDNA in nucleus, namely $1.0-2.9 \mathrm{C}$ and $3.0-6.9 \mathrm{C}$ for $\mathrm{K}-27(10 \mathrm{~S})$ and 1.0-2.9C and 3.0-8.9C for K-27(Rzh). The circadian dynamics' of alteration of abovementioned cell portions at $12-15^{\text {th }}$ days of growth for $\mathrm{K}-27(10 \mathrm{~S})$ and 9-1 $1^{\text {th }}$ days for K-27(Rzh) are shown on Fig.1. The shares of specific morphometrical classes for circadian dynamics, further combined into subpopulations, are presented in Table 1. During indicated time interval two dominating subpopulations were found, namely the subpopulation of $\mathrm{K}-27(10 \mathrm{~S})$ with $3.0-6.9 \mathrm{C}$ of rcDNA in nucleus was $70.6 \%(0.71)$ and subpopulation 

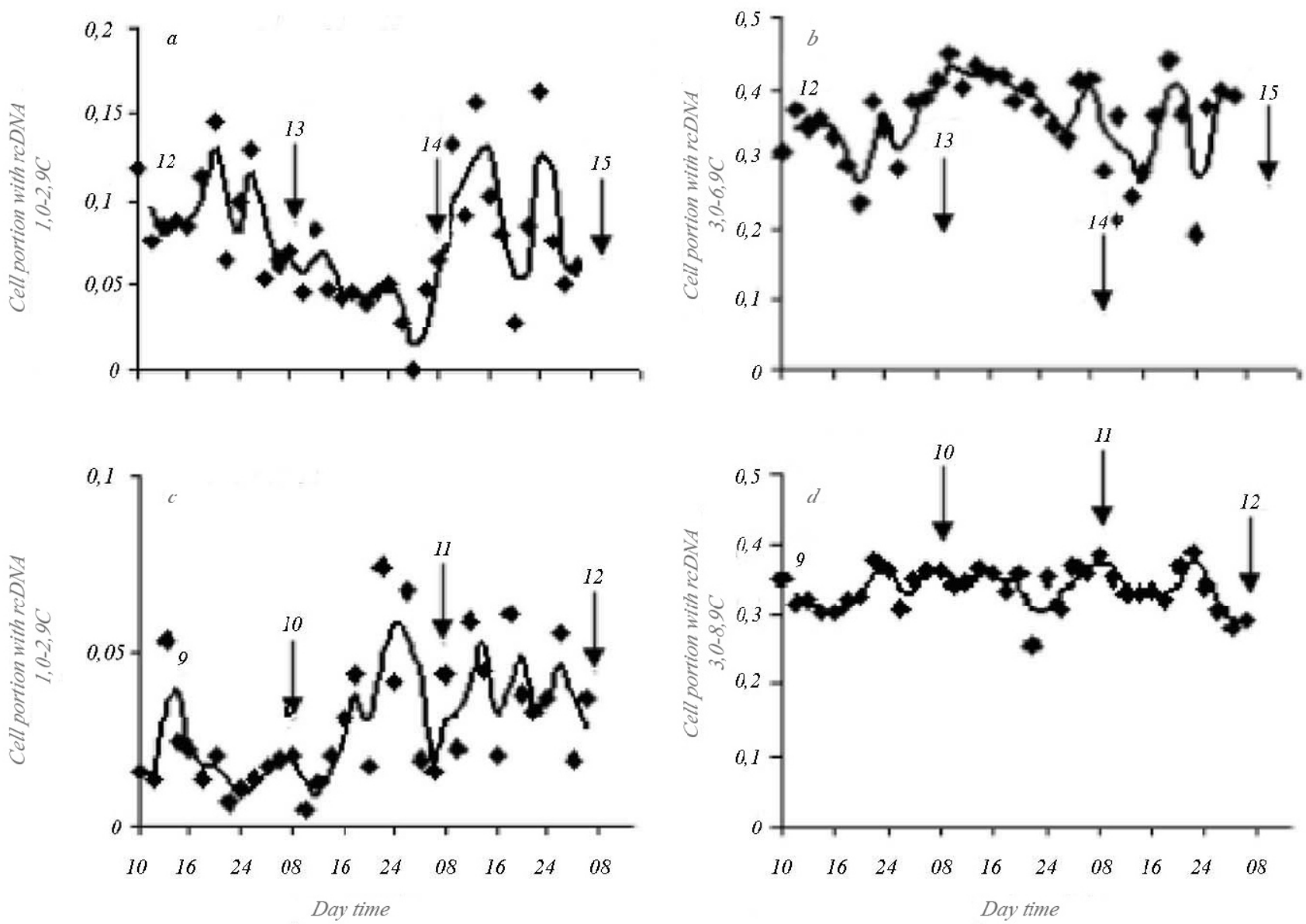

Fig.1 Alteration dynamics of cell portion (where 1 is assumed to be $100 \%$ ) with different relative DNA content in nucleus under standard cultivation conditions in $10 \mathrm{~S}$ medium (K-27(10 S) variant) $(a, b)$ and under conditions of submerged cultivation in liquid medium Rzh $\left(\mathrm{K}-27\right.$ (Rzh) variant) $(c, d)$ during $12-15^{\text {th }}$ and $9-12^{\text {th }}$ days of cultivation. Arrows indicate the beginning of the corresponding day of growth.

of K-27(Rzh) with 3.0-8.9 C of rcDNA - 82\% (0.82). Thus, on circadian level during three days of passaging, there was no change of dominating cell subpopulation, according to rcDNA in nucleus.

For both cell variants (K-27 (10 S) and K-27(Rzh)) two mechanisms of proliferation were defined, namely, mitotic and amitotic proliferation. Their circadian dynamics' are shown on Fig.2.

Both cell variants showed similar circadian rhythms of mitoses during three days of observation. Six main peaks were observed in both cases; there were two peaks of mitotic activity daily, positions of which varied from day to day (Fig.2, $a, b$ ). Changing of the cultivation conditions influenced neither average nor maximal MI values, which remained for both cell cultures at the level of 0.14 and $0.4 \%$ respectively.
The dynamics of AMI for both culture variants showed also six main peaks; however, the curve shape was somewhat different (Fig.2, $c, d)$. For K-27(10 S) the average AMI was about $1.1 \%$, exceeding MI $(0.14 \%)$ almost tenfold, while the average AMI for K-27(Rzh) variant was $0.52 \%$ that was about three times higher than MI $(0.14 \%)$. Maximal AMI values were higher for K-27(10 S) variant, i.e. $2.5 \%$ comparing to $1.2 \%$ for $\mathrm{K}-27$ (Rzh).

Theoretical basis that allows interpretation of experimental data by phenomenological system of equations was published in articles of Zotina and Zotin [3, 4], where the main principles of thermodynamic approach for cell and tissue cultures were stated. In particular, in the reference [5], the biological significance was given to fluxes and forces for studying tissue culture of $R$. serpentina at the passage level and evidences 

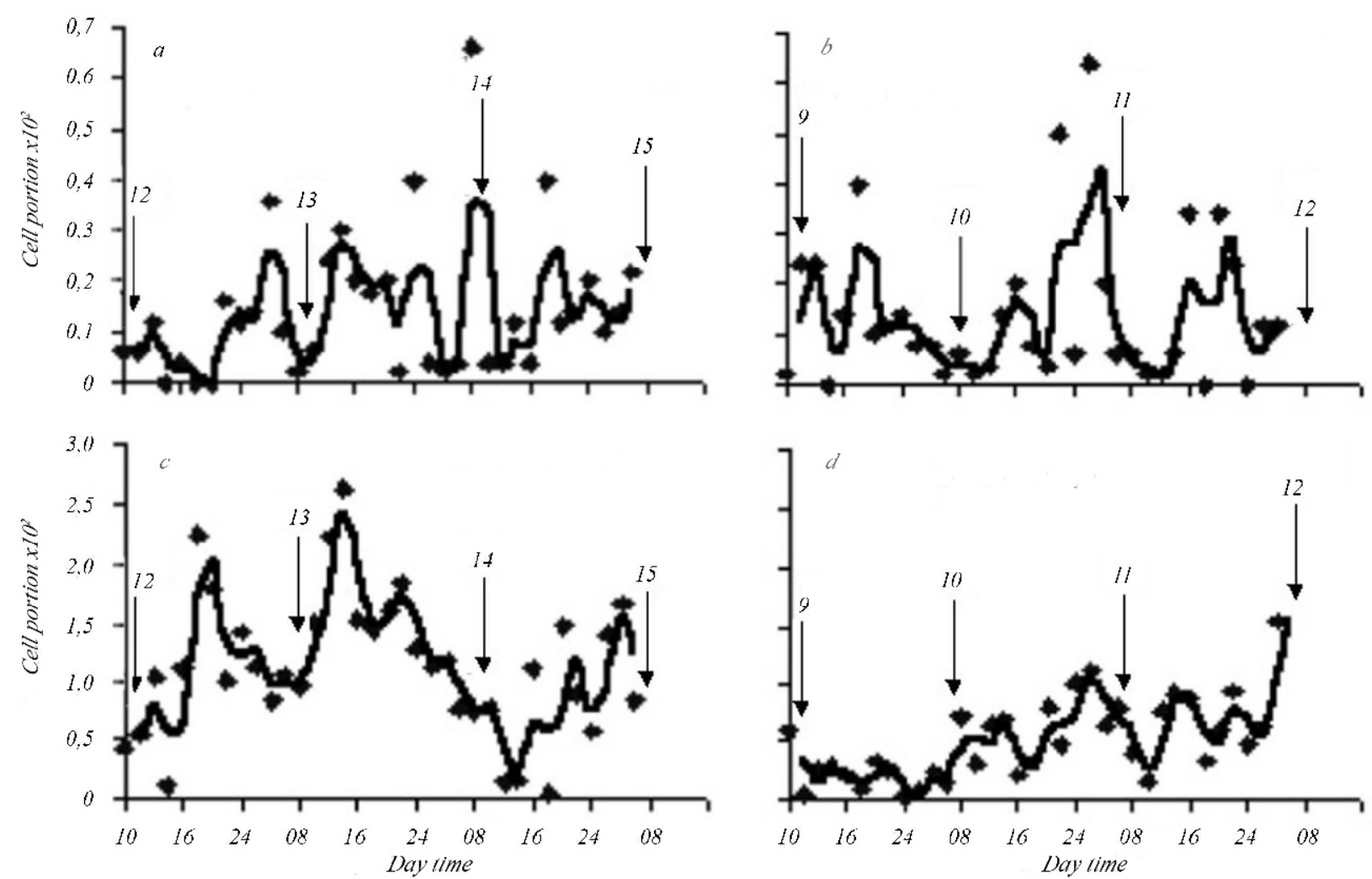

Fig.2 Dynamics of change of mitoses $(a)$ and amitoses $(b)$ quotas under standard cultivation conditions in 10S medium (K-27(10 S) variant), as well as of mitoses $(c)$ and amitoses $(d)$ quotas under conditions of submerged cultivation in liquid medium Rzh (K-27(Rzh) variant) during $12-15^{\text {th }}$ and $9-12^{\text {th }}$ days of cultivation, respectively. Arrows indicate the day of growth beginning. For the convenience of thermodynamic equations calculation, instead of proliferation indexes (\%) we used the mitoses or amitoses quotas where 1 is assumed to be

were produced proving the possibility of application of the developed thermodynamic model with corresponding values of fluxes and forces.

In our previous work [6], we have reported the results for three culture variants, for which the values of phenomenological coefficients have been established. In the same work [6] the notion of adaptation coefficient has been introduced to characterize the change of the value of "conductivity" coefficient of an appropriate characteristic (the gradient of which is the dynamics of the cell portion with this characteristic under system relaxation after the cell transfer - that is a force by itself) in comparison to the adaptation coefficient of the biomass accumulation property (always equal to 1 ) in the "conductor". The "conductor" is a tissue culture, which is placed into the medium with certain content of nutrient substances, creates a specific concentrations gradient of these substances during growth and differentiation of cells by different ways resulting in the change of cell portion of respective specialization during passage.

Trying to proceed to circadian level of studying, we used the data, previously obtained by Kunakh et alt. [2], as well as experiments and models of yeast culture under conditions of continuous cultivation, opposite to conditions of periodic cultivation, used by us [19]. From the last work we have also taken the idea to consider the "age" of cells and applied it for generation of a corresponding system of phenomenological equations. Our investigated system was ergodic, we did not synchronize cell divisions by any method, including special light treatment, and thus, it was a system with "a clock switched off" [9].

It is known that it's almost impossible to distinguish the length of mitotic cycle and cycles of epigenetic processes using specific times of relaxation [20]. Therefore, we probably observe on the curves of circadian dynamics the spectrum of oscillations of metabolic processes, 

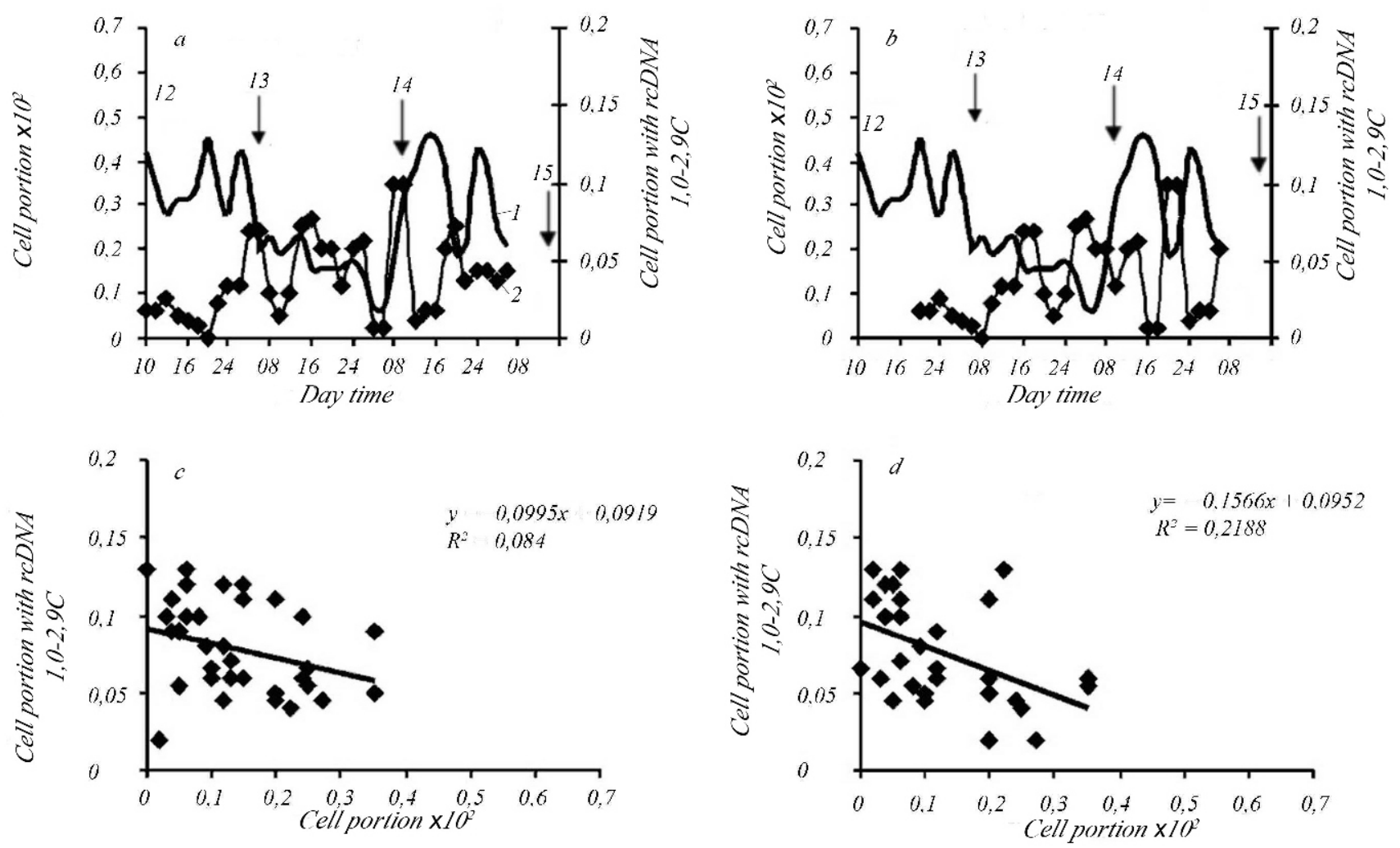

Fig.3 Circadian dynamics of change of cell portion with 1.0-2.9 C of rcDNA (curve 1) and mitoses quota (curve 2) during $12-15^{\text {th }}$ days of growth of K-27(10 S) cells of $R$. serpentina under cultivation on $10 \mathrm{~S}$ agar medium: without any shift $(a)$ and with 12 hours-shift of the mitotic index curve relative to the curve of cell portion with 1.0-2.9 C of reDNA $(b)$. The equations of fitted regression lines, obtained by the least-squares method, are shown on the plot. Criterion statistic values for $\mathrm{R}^{2}$ showed on plot $c$ is $F_{1,34}=3.13$ (does not exceed the upper $5 \%$ threshold of $F$-distribution for $N=36\left(F_{1,34}=4.17\right)$ ), and showed on plot $d$ is $F_{1,28}=7.84$ (exceed the upper 5\% threshold of $F$-distribution for $\left.N=30\left(F_{1,28}=4.20\right)\right)$. This means the absence of linear dependence in the first case and the presence of linear dependence in the second one.

not related to light clock, that is why the oscillation period changes during periodic cultivation (along with depletion of nutrient substances, provided after the culture transfer) [2]. This consideration has also given us the reason to apply the thermodynamic approach.

Therefore, the contribution of each alteration dynamics of the portion of proliferating cells into alteration dynamics of the portion of corresponding cell subpopulation, according to rcDNA in nucleus, can be described in general by the system of phenomenological equations:

$$
\begin{gathered}
I_{l}(t)-I_{l m}(t=m)= \\
=\sum_{s} \sum_{k=m}^{m+36} A_{l s} R_{l s k}(t+k) X_{s k}(t+k),
\end{gathered}
$$

where $I_{l}(t)$ - flow of the cell subpopulation with rcDNA 1.0-2.9 $\mathrm{C} ; I_{2}(t)$ - flow of cell subpopulation with rcDNA 3.0-6.9 C for $\mathrm{K}-27(10 \mathrm{~S})$ or 3.0-8.9 C for $\left.\mathrm{K}-27(\mathrm{Rzh}) ; I_{l}(t), l=1,2\right)$; phenomenological coefficients (and forces as well) have more complicated composition than $L_{l s}=R_{l s k} A_{l s k}\left(X_{l k}(t), s=1,2\right)$ due to the contributions of previous force values into subsequent values of the flow (see interpretation of symbols $t, m$, $\mathrm{k})$. Specific value and sign of correlation coefficient $\left(\mathrm{R}_{\mathrm{lsk}}\right)$ indicate the contribution of particular alteration dynamics of proliferating cell portion (mitoses or amitoses), i.e. the thermodynamic force: $X_{1}(t+k)$ or $X_{2}$ $(t+k)$ - into a specific biological flux $I_{1}(t)$ or $I_{2}(t)(t-$ time, $m$ - initial value of $\mathrm{t}$, when the first sample for circadian dynamics study was taken out, $k$ - number of points, which reflects the shift of force value dynamics relative to fluxes value dynamics, to consider the con- 


\section{TTable 2}

Correlation coefficients $R_{l s k}$ of dynamics of fluxes $*$ and forces $* *$ with successive shifts in $k$ points every two hours ( $k=1$ ? 33) of quantitative proliferation dynamics relative to quantitative dynamics of corresponding cell subpopulation, according to rcDNA in

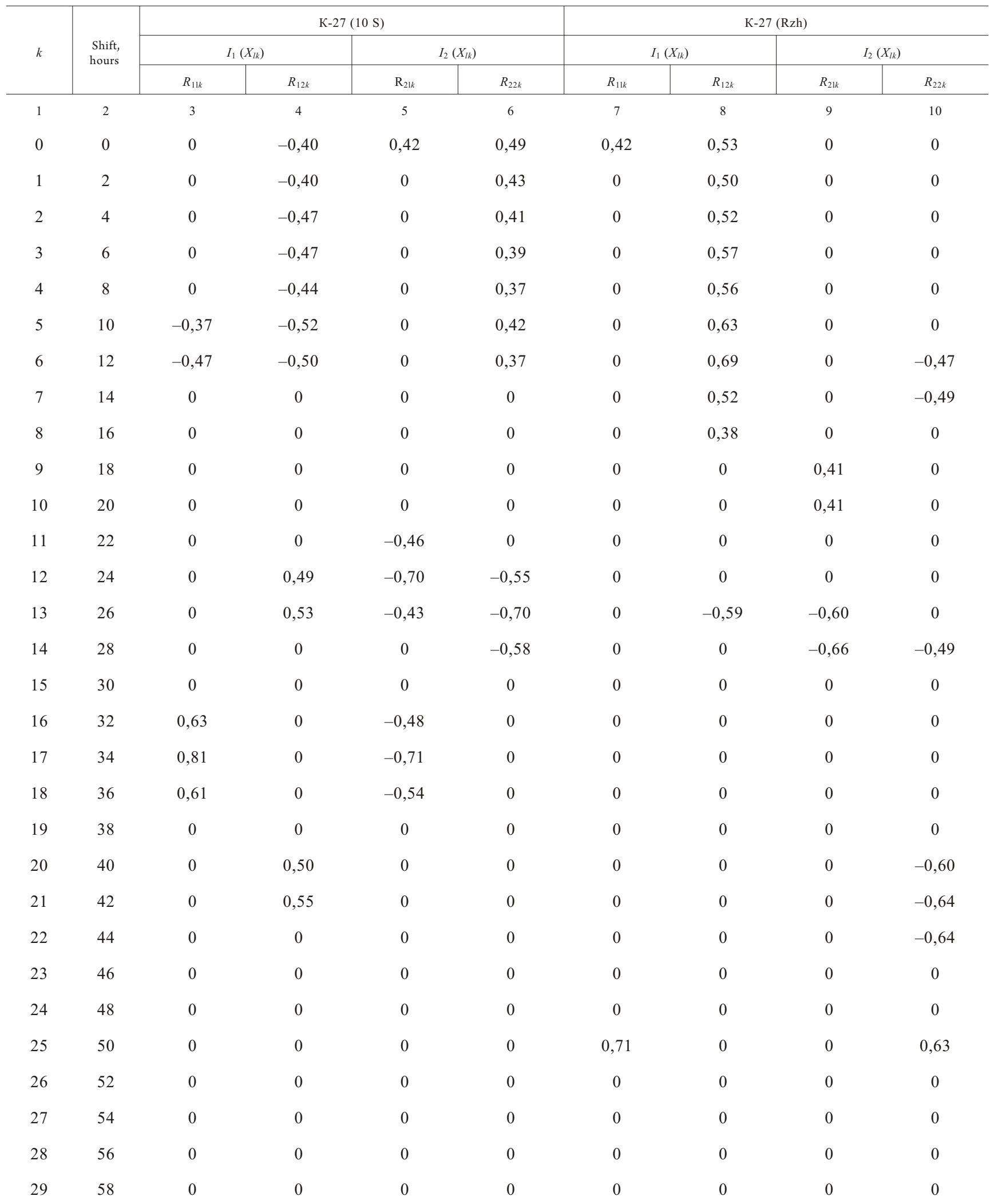


Continuation of Table 1

\begin{tabular}{c|c|c|c|c|c|c|c|cc}
\hline 1 & 2 & 3 & 4 & 5 & 6 & 7 & 8 & 9 \\
\hline 30 & 60 & 0 & 0 & 0 & & $-0,88$ & 0,82 & 0 \\
31 & 62 & 0 & 0 & 0 & 0 & 0 & 0 & 0 \\
32 & 64 & 0 & 0 & 0 & 0 & 0 & 0 & 0 \\
33 & 66 & 0 & 0 & 0 & 0 & 0 & 0 & 0 \\
\hline
\end{tabular}

Note: *Flux $\mathrm{I}_{1}$ - dynamics of portion of cell subpopulation with 1.0-2.9 C of rcDNA in nucleus; flux $\mathrm{I}_{2}-d y n a m i c s$ of portion of cels subpopulation with 3.0-6.9 C of rc DNA in nucleus for K-27 (10 S), and 3.0-8.9 C for K-27 (Rzh); ** force $X_{l k}-$ dynamics of cell portion, proliferating by mitoses $(l=1)$ or amitoses $(l=2)$.

Paired linear regression method was used to compare the dynamics. Criterion statistics was calculated by the formula $F_{1, N-2}=$ $(N-2) R^{2} /\left(1-R^{2}\right)$, for non-zero correlation coefficients the criterion statistic value was higher than $5 \%$ of treshhold limit for F-distribution, namely, $F_{1,34}=4,17$ for $N=36$ (first line $-k=0$ ) and $F_{1,4}=7,71$ for $N=6$ (31st line $-k=30$ ).

tributions of preceding values of biological forces into the moments of time $t+m$ to biological fluxes in the moments of time $t+m+k$ ) (Fig.3, Table 2); $A_{l s}$ - adaptation coefficients, i.e. particular values for every investigated system are presented below.

Experimental values of the dynamics of fluxes and their values, calculated from equations are presented on Fig.4. To evaluate adequacy of computed curves we used the method of estimating distribution normality with zero mathematical expectation of the deviations squares between compared curves. This approach demonstrates the similarity of computed curves at least for the last two days from three days period of observation (first day deviations may be the consequence of not taking into account the contributions of forces from the previous day).

Comparison of contribution of mitoses and amitoses dynamics into dynamics of cell portion with different $r c D N A$ in nucleus. After changing of cultivation conditions, we observed the differences in correlation between some cell subpopulations dynamics, according to their rcDNA, and portion of proliferating cells. Positive contribution of MI and AMI into the change of cell portion with 3.0-6.9 $\mathrm{C}$ of rcDNA and negative contribution into the change of cell portion with 1.0-2.9 C of rcDNA were observed for K-27(10 S) variant without any temporal shift and with 2-12 hours shift of dynamics of proliferating cell portion relatively to dynamics of the portion of cell subpopulation with different rcDNA.
Positive contribution of $\mathrm{MI}$ and AMI into the change of cell portion with 1.0-2.9 C of reDNA and negative contribution of AMI (without correlation to MI) into the change of portion of cell subpopulation with 3.0-6.9 C (Table 2) were observed for K-27(Rzh) variant without any temporal shift and with the 2-16 hours shift along $t$-axis to the right. Thus, during investigated interval of time, the proliferation activity of both cultivation variants that goes forward the appearance of certain cell subpopulation on the above-mentioned shift, probably determines the coming out of precursor cells of the same subpopulation, which are different for investigated cultivation variants.

The contributions of MI and AMI into the change of the cell portion of both subpopulations for K-27(10 S) variant, with more than 16 hours-shift of dynamics of proliferation indexes along $t$-axis to the right side, relative to the dynamics of the cell portion of corresponding subpopulation with different rcDNA, were observed to change contrarily: they become positive for subpopulation 1.0-2.9 C, and negative - for 3.0-6.9 C. The dynamics of MI and AMI for K-27(Rzh) variant with the shift along $t$-axis to the right side relative to dynamics of corresponding subpopulations according to their rcDNA make both positive and negative contributions into the change of cells portion of both subpopulations with different rcDNA (Table 2).

Thus, under the changing of cultivation conditions, the proliferation is switched to the production of opposite subpopulation of cells (in our case - to cells with higher values of rcDNA, i.e. polyploidy cells). 

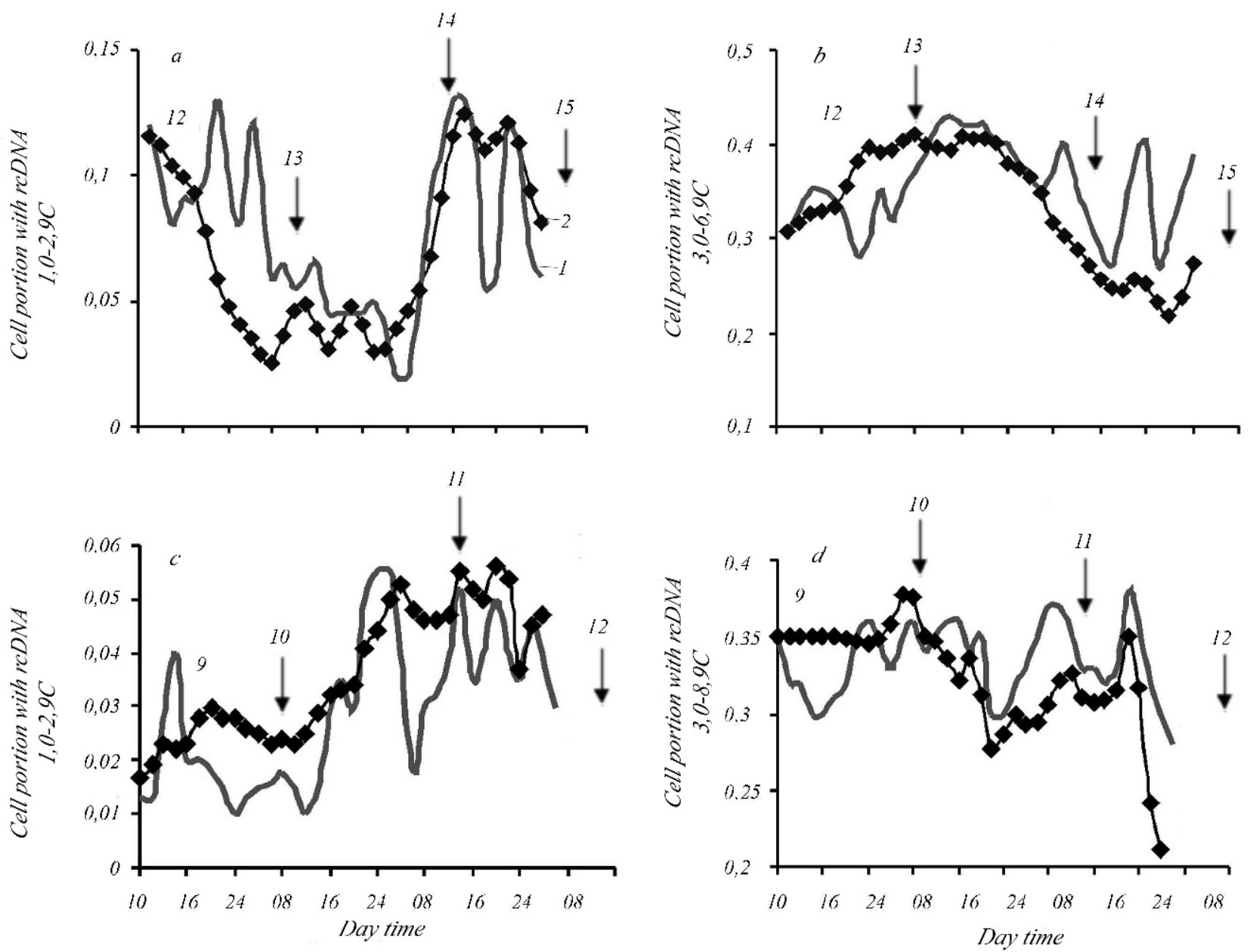

Fig.4 Alteration dynamics of portion of cell subpopulation with 1.0-2.9 C $(a)$ and 3.0-6.9 C $(b)$ of rcDNA in nucleus for K-27(10 S) variant during $12-15^{\text {th }}$ days of cultivation, and portion of cell subpopulation with 1.0-2.9 C $(c)$ and 3.0-8.9 C $(d)$ of rcDNA in nucleus for K-27(Rzh) variant during $9-12^{\text {th }}$ days of cultivation. For all plots $(a-d)$, curve 1 is the flux $I_{l}(t)$, determined from the experiment; curve $2-$ flux $I_{l}(t)$, determined from the equation, $l=1,2)$. All experimental data were smoothed by two points moving average method. Arrows indicate the beginning of corresponding day of growth.

Moreover, when comparing the cultivation variants, we can see the change of cell subpopulations according to their rcDNA in nucleus. The dynamics of this change, with some temporal shift, is positively contributed by the dynamics of biological forces mitoses and amitoses.

Analysis of adaptation coefficients of biological forces and fluxes $A_{l s}$ under the change of cultivation conditions. It was found that the change of cultivation conditions influenced the value of adaptation coefficient $\mathrm{A}_{\mathrm{ls}}$ (computed according to the above-mentioned system of equations) of the dynamics of some proliferation indexes - biological forces to a specific flux. The adaptation coefficients for K-27(10 S) variant were de- scribed by a matrix: for the system of equations with initial values of $m=144$ (time-point of sample withdrawing, corresponding to 10.00 o'clock of the $12^{\text {th }}$ day); $\mathrm{I}_{I m}=0.12$ (the value of flux of cell subpopulation with 3.0-6.9 C of rcDNA at the starting point of sample withdrawing); $\mathrm{I}_{2 m}=0.3$ (the value of flux of cell subpopulation with 3.0-6.9 $\mathrm{C}$ of rcDNA at the starting point of sample withdrawing). Adaptation coefficients for K-27(Rzh) variant were described by a matrix: for the system of equations with initial value of $m=108$ (time-point of sample withdrawing, corresponding to 10.00 o'clock of the $9^{\text {th }}$ day); $\mathrm{I}_{I m}=0.013$ (the value of flux of cell subpopulation with 1.0-2.9 $\mathrm{C}$ of rcDNA at the starting point of sample withdrawing); $\mathrm{I}_{2 m}=0.35$ 
(the value of flux of cell subpopulation with 3.0-8.9 C of rcDNA at the starting point of sample withdrawing). As can be seen, the adaptation coefficients of both biological forces relative to the flux of cell subpopulation with 1.0-2.9 C of rcDNA for K-27(10 S) variant were equal. In the case of cell subpopulation 3.0-6.9 C, the adaptation coefficient of biological force-dynamics of change of mitoses quota was 1.67 -fold higher than that of the other biological force - dynamics of change of amitoses quota. For the biological flux of cell subpopulation with 1.0-2.9 C of rcDNA for K-27(Rzh) cultivation variant, the adaptation coefficient of biological force - dynamics of change of mitoses quota was 5-fold higher than the value of the same parameter for amitoses. In the case of second flux-dynamics of cell subpopulation with 3.0-8.9 $\mathrm{C}$ of rcDNA, the adaptation coefficient of biological force-dynamics of the change of mitoses quota was 60 -fold higher than the value of the same parameter for amitoses.

Comparative analysis evidenced that under the change of cultivation conditions the adaptation coefficient of dynamics of change of mitoses quota increased 12-fold and the same parameter of amitoses quota decreased 3-fold towards the production of cells with high values of rcDNA, related to differentiation, due to accumulation of indoline alkaloids or creation of tracheids, as it was shown for the passage hierarchical level.

Conclusions. Mathematical model, designed to describe physical, chemical, and biological systems with conjugated processes, was modified to consider the "age" of cells. It allows determining the correlation between alteration dynamics of cell portion with different rcDNA in nucleus (as biological fluxes) and dynamics of portion of mitotic and amitotic proliferating cells (as biological forces) at circadian hierarchical level in tissue culture.

The analysis of correlation coefficients between forces and fluxes showed that the change of cultivation conditions leads to the change of the cell dynamics with different relative DNA content in nucleus. This dynamics is positively contributed, with some temporal shift, by biological forces - the dynamics of mitoses and amitoses quotas.

The response of $R$. serpentina tissue culture to the change of cultivation conditions is followed by the alteration of adaptation coefficient of the corresponding force to the flux after the transition to submerged cultivation. The contribution of dynamics of mitoses quotas into the increase in cell number with high DNA content in the nucleus has been revealed. High values of the adaptation coefficients may be an evidence for the predomination of mitotic proliferation in increasing the cell portions, which then differentiate by polyploidization into the cells, producing indoline alkaloids. The response of R. serpentina tissue culture to the change of cultivation conditions is followed by the alteration of adaptation coefficient of the corresponding force to the flux after the transition to submerged cultivation. The contribution of dynamics of mitoses quotas into the increase in cell number with high DNA content in the nucleus has been revealed. High values of the adaptation coefficients may be an evidence for the predomination of mitotic proliferation in increasing the cell portions, which then differentiate by polyploidization into the cells, producing indoline alkaloids.

\section{I. Ю. Парнікоза, Н. Ю. Мірюта, В. І. Адонін, В. А Кунах}

Циркадна динаміка структури клітинних популяцій Rauwolfia serpentina Benth. за різних умов культивування in vitro

Резюме

За допомогою математичного апарату, розробленого для характеристики фізичних, хімічних та біологічних систем, проиеси в яких $\epsilon$ спряженими, який отримав назву термодинамічного підходу, досліджено та описано залежності між динамікою часток клітин з різним відносним вмістом ДНК в ядрі (біологічні потоки) та показників проліферації-мітозів та амітозів - (біологічні сили) на циркадному ієрархічному рівні за зміни умов культивування для високопродуктивного штаму $K-27 R$. serpentina - продуцента протиаритмічного алкалоїду аймаліну.

Ключові слова: культура тканин рослин, Rauwolfia serpentina, uиркадна динаміка, клітинні популяиї іn vitro.

\section{И. Ю. Парникоза, Н. Ю. Мирюта, В. И. Адонин, В. А. Кунах}

Циркадная динамика структуры клеточных популяций Rauwolfia serpentina Benth. в различных условиях культивирования in vitro

Резюме 
С помощью математического аппарата, разработанного для характеристики физических, химических и биологических систем, прочессы в которых являются сопряженными, получившего название термодинамического подхода, исследованы $u$ описаны зависимости между динамикой частоты клеток с разным относительным содержанием ДНК в ядре (биологические потоки) и показателей пролиферации - митозов и амитозов - (биологические силы) на циркадном иерархическом уровне при изменении условий культивирования для высокопродуктивного штамма $K-27 R$. serpentina - продуиента противоваритмического алкалоида аймалина.

Ключевые слова: культура тканей растений, Rauwolfia serpentina, uиркадная динамика клеточных популяций in vitro.

\section{REFERENCES}

1. Lee $M$. The chromosomal basis of somaclonal variation // Ann. Rev. Plant Physiol. Plant Mol. Biol.-1988.-39.P. 413-437.

2. Кунах В. А. Біотехнологія лікарських рослин. Генетичні та фізіолого-біохімічні основи.-Київ: Логос, 2005.-730 c.

3. Зотин А. И., Зотина Р. С. Термодинамический подход к проблемам развития, роста и старения // Журн. общ. биологии.-1969.-30, № 1.-С. 94-109.

4. Зотина Р. С., Зотин А. И. Объединенные уравнения роста // Журн. общ. биологии.-1973.-34, № 4.-С. 606-616.

5. Мирюта Н. Ю., Парникоза И. Ю., Аль-Аммури Ю., Кунах B. A. Применение термодинамического подхода для изучения динамики клеточных популяций in vitro на примере культуры тканей Rauwolfia serpentina Benth.-продуцента индолиновых алкалоидов // Биотехнология.-2006.№ 2.-C. 78-95.

6. Парникоза І. Ю., Мирюта Н. Ю., Аль-Аммури Ю., Кунax $B . A$. Динаміка клітинних популяцій Rauwolfia serpentina Benth. в різних умовах культивування in vitro // Біополімери і клітина.-2008.-24, № 4.-С. 300-310.

7. Ripperger J. A., Shearman L. P., Reppert S. M., Schibler U. Clock, an essential pacemarker component, controls expression of circadian transcription factor DBP // Genes and Develop.-2000.-14.-P. 679-689.

8. Чалый A. В. Неравновесные процессы в физике и биологии.- Киев: Наук. думка, 1997.-183 с.

9. Bianchi M. M. Collective behavior in gene regulation: Metabolic clocks and cross-talking // FEBS J.-2008.-275.P. 2356-2363.
10. Palumbo M. C., Farina L., De Santis A., Giuliani A., Colosimo A., Morelli G., Ruberti I. Collective behavior in gene regulation: Post-transcriptional regulation and the temporal compartmentalization of cellular cycles // FEBS J.- 2008.275.-P. 2364-2371.

11. Klevecz R. R., Li C. M., Marcus I., Frankel P. H. Collective behavior in gene regulation: The cell is an oscillator, the cell cycle a developmental process // FEBS J.-2008.-275.P. 2372-2384.

12. Кунах В. А., Аль-Аммури Ю., Мирюта Н. Ю., Можилевская Л. П. Накопление индолиновых алкалоидов клеточными линиями раувольфии змеиной при поверхностном и глубинном выращивании // Біополімери і клітина.2006.-22, № 2.-C. 149-156.

13. Каухова И. Е., Воллосович А. Г., Цыганков В. А. Выбор питательной среды для глубинного культивирования тканей раувольфии змеиной (Rauwolfia serpentina Benth.) // Растит. ресурсы.-1981.-17, № 2.-С. 217-224.

14. Кунах В. А., Можилевская Л. П., Губарь С. И. Особенности получения и продуктивность суспензионных клонов раувольфии змеиной Rauwolfia serpentina Benth. in vitro // Биотехнология.-2001.-№ 4. -C. 9-21.

15. Деклараційний пат. України № 12083/п1 від 27.03.2006, Спосіб вирощування калюсної культури тканин раувольфії зміїної Rauwolfia serpentina Benth.-продуцента аймаліну / В. А. Кунах, Ю. Аль-Аммурі, Л. П. Можилевська, Н. Ю. Мірюта // Бюл. № 5.

16. Kiernon J. A. Histological and histochemical methods. Theory and practice.-New-York: Pergamon press, 1990.$364 \mathrm{p}$.

17. Парнікоза І. Ю., Мірюта Н. Ю., Ал-Амурі Ю., Адонін В. І., Кунах B. A. Особливості процесів проліферації та диференціації в культурі тканин Rauwolfia serpentina Benth. // Вісн. Укр. тов-ва генетиків і селекціонерів.-2006.-4, № 2.-C. 210-216.

18. Поллард Дж. Справочник по вычислительным методам статистики.-М.: Финансы и статистика, 1982.-344 с.

19. Печуркин Н. С., Брильков А. В., Марченкова Т. В. Популяционные аспекты биотехнологии.-Новосибирск: Наука, 1990.-170 c.

20. Гудвин Б. Аналитическая физиология клеток и развивающихся организмов.-М.: Мир, 1979.-287 с.

UDC 576.53:581.143.6

Received 18.02.08 